\title{
The Relationship Between Fulfilment of Basic Needs with the Incidence of Stunting In Toddlers
}

\section{Endang Surani and Endang Susilowati}

Sultan Agung Islamic University, Semarang, Central Java, Indonesia

\begin{abstract}
Introduction: The prevalence of toddlers who very short and short at the age of 0-59 months in Indonesia is still high. One cause of stunting is lack of nutrition, mainly in the first 1000 days of life. The purpose of this study was to identify the relationship between the fulfilment of basic needs with the incidence of stunting in toddlers.
\end{abstract}

Methods: A quantitative analytic research methods using cross-sectional approach was applied on this study. The sample was100 toddlers collected by purposive sampling technique. The questionnaires were used to measure the fulfilment of the basic needs of children and included questions about physical, emotion and stimulation. The data were analysed using Chi-Square.

Results: There was a relationship between fulfilment of the basic needs in physical and emotion category with stunting ( $p$ value of 0.000 ), while there was no relationship between fulfilment of basic needs in the category of stimulation with stunting ( $\mathrm{p}$ value of 0.090 ).

Conclusion: The fulfilment of the basic needs of physical and emotion affects the condition of toddlers with stunting. Thus, all of children should get exclusive breastfeeding, appropriate complementary feeding, early childhood education programme, attend an Integrated Healthcare Centre routinely, have adequate access to immunisation services.

\section{ARTICLE HISTORY}

Received: January 23, 2020

Accepted: March 30, 2020

\section{KEYWORDS}

basic needs of children; toddler; stunting

\section{CONTACT}

Endang Susilowati \esusilowati@unissula.ac.id $\risingdotseq$ Sultan Agung Islamic University, Semarang, Central Java, Indonesia

Cite this as: Surani, E., \& Susilowati, E. (2020). The Relationship Between Fulfilment of Basic Needs with the Incidence of Stunting In Toddlers. Jurnal Ners, 15(1), 26-30. doi:http://dx.doi.org/10.20473/jn.v15i1.17286

\section{INTRODUCTION}

More than two million deaths of children under 5 years in the world are directly related to malnutrition, especially wasting and stunting. According to data released by UNICEF, there are around 195 million stunted children who live in poor and developing countries (Wiyogowati, 2012). The World Health Organization (WHO) placed Indonesia as the third country with the highest stunting prevalence rate in Asia in 2017, reaching $36.4 \%$. However, in 2018, the figure continued to decline by $23.6 \%$. From the same data, it is also known that stunting in children under five in Indonesia dropped to $30.8 \%$. In Indonesia in 2017 , the prevalence of toddlers was very short and short at the age of 0-59 months by around $9.8 \%$ and $19.8 \%$, respectively and, in 2018 , around $30.8 \%$ of toddlers were in the very short and short categories while in Central Java Province in 2018 it was around 31.22\% (Riskesdas, 2018).

Stunting is a syndrome in which linear growth failure functions as a marker of several pathological abnormalities associated with increased morbidity and mortality, loss of potential for physical growth, reduced nerve development and cognitive function and increased risk of chronic disease in adulthood (Kemenkes, 2018). Stunting can occur as a result of malnutrition, especially in the first 1000 days of life. There are multidimensional factors that cause stunting, including poor parenting practices, limited health services including ante natal care, lack of access to nutritious food, lack of access to clean water and sanitation (Kemenkes, 2018).

The nutritional status of children less than five years old is very influential in the process of growth and development. In stunting children there is a growth failure (growth faltering) that starts in the 
womb and lasts until the child is 2 years old. This problem can occur due to lack of protein energy as one of the main nutritional problems that occur in toddlers and which is very influential on the child's growth and development process (UNICEF, 2010).

One treatment that can prevent the occurrence of stunting in children is to meet the basic needs during growth and development, namely fostering, caring and homing needs; these basic needs affect nutritional status. Basic needs greatly affect the nutritional status is the fulfilment of fostering needs because it is directly related to the physical environment of children (Maria \& Adriani, 2009).

Parenting is a way parents treat their children by looking after, caring for, and educating them. From the way the parents treat them it will reflect their own characteristics which will affect the child's attitude patterns later on. Basic needs are very necessary to support the growth and development of children. These basic needs can be grouped into three, namely "asih, asah, and asuh" (Soetjiningsih, 2013). The purpose of this study was to determine whether there is a relationship between meeting basic needs with the incidence of stunting toddlers.

\section{MATERIALS AND METHODS}

This research used observational analytic research with cross-sectional approach. The research was conducted in a village of Demak Regency for eight months from May - December 2019. The population in this study were 155 toddlers who were stunted. The sampling technique in this study was purposive sampling method. The inclusion criterion was minimum age of 2 years and a maximum of 5 years. Samples obtained were 100 respondents.

The instrument used in this study was questionnaires containing the child's identity, mother identity and 41 questions about fulfilment of the basic needs of children, which included 25 questions for physical, 10 questions for emotion, and six questions for stimulation. The independent variable in this study was the fulfilment of the basic needs of children and the dependent variable was stunting. This study has received ethical approval from the Medical/Health Research from the Commission of the Faculty of Medicine in UNISSULA with No. 642 / X / 2019 / Bioethics Commission.

\section{RESULTS}

Based on Table 1, it can be seen that $63.0 \%$ of respondents are included in the high-risk age category, $81.0 \%$ have basic education, $51.0 \%$ are housewives, $92.0 \%$ earn below the minimum wage payment, $60.0 \%$ are male, $50.0 \%$ were in short status and $50.0 \%$ were very short.
The results of the study (Table 2) found that $70.0 \%$ of respondents in the low risk category had toddlers with a short status and $56.0 \%$ were very short, respondents with basic education $80.0 \%$ had short toddlers and $82.0 \%$ were very short, Respondents as housewives, $50.0 \%$ had short toddlers and $52.0 \%$ were very short; income less than MWP, $90.0 \%$ had short toddlers and $94.0 \%$ were very short while for gender of stunting in toddlers $54.0 \%$ are short and $66.0 \%$ are very short occurring in boys under five. The characteristics of respondents had no significant relationship with stunting in toddlers ( $p$ value $>0.05$ ), but there was a significant relationship between fulfilment of the basic needs, including physical, emotion and stimulation with the incidence of stunting in toddlers ( $p$ value $0.000<.05$ ).

\section{DISCUSSION}

The fulfilment of the basic needs of physical and emotion affects the condition of toddlers with stunting. According to the director of the budget in the field of human and cultural development in 2018, stunting is caused by multidimensional factors including bad child care practices, meaning children aged 0-6 months are not getting exclusive breastfeeding and children aged $>6-24$ months do not get the appropriate complementary feeding, while children aged 3-6 years old are not registered in an early childhood education programme, show decreased level of attendance in Integrated Healthcare Centres, and do not get adequate access to immunisation services (Direktur Anggaran Bidang Pembangunan Manusia dan Kebudayaan, 2018). The results showed that for toddlers with both short and very short status, neither physical nor emotional needs were met. Based on the questionnaire, it is known that the majority of infants do not get exclusive breastfeeding and have received complementary feeding before the age of 6 months. The complementary feeding given is not suitable for the baby's age, whereas in children aged $12-60$ months the feeding does not meet balanced nutrition. This includes bad parenting and child care needs not being met. This is in line with the research of Rahmayana, Ibrahim, and Darmayati (2014) which stated there was a significant relationship between feeding practices with stunting in toddlers. Feeding infants and children is an important foundation in the growth process. Globally, around $30 \%$ of children under five years who are stunted are a consequence of poor feeding practices and recurrent infections (Rahmayana et al., 2014).

Maternal nutrition knowledge in Mimika Regency was found to be $80 \%$ of respondents in good category and $20 \%$ in less category. The level of maternal education also determines the convenience of mothers in absorbing and understanding the nutritional knowledge gained. This can be the basis for distinguishing the appropriate extension methods. From the family's nutritional importance, 


\section{E. SURANI ET AL.}

Table 1. Respondents' Characteristics $(n=100)$

\begin{tabular}{|c|c|c|}
\hline Variables & $\mathbf{n}$ & $\%$ \\
\hline \multicolumn{3}{|l|}{ Age of Respondent } \\
\hline Low Risk & 37 & 37.0 \\
\hline High Risk & 63 & 63.0 \\
\hline \multicolumn{3}{|l|}{ Mother's Education } \\
\hline Primary Education & 81 & 81.0 \\
\hline Secondary Education & 18 & 18.0 \\
\hline Higher Education & 1 & 1.0 \\
\hline \multicolumn{3}{|l|}{ Mother's Occupation } \\
\hline Housewife & 51 & 51.0 \\
\hline Labourers & 23 & 23.0 \\
\hline Private Employee & 26 & 26.0 \\
\hline \multicolumn{3}{|l|}{ Family Income } \\
\hline$<$ MWP & 92 & 92.0 \\
\hline > MWP (Minimum Wage Payment) & 8 & 8.0 \\
\hline \multicolumn{3}{|l|}{ Gender of toddlers } \\
\hline Male & 60 & 60.0 \\
\hline Female & 40 & 40.0 \\
\hline \multicolumn{3}{|l|}{ Status of Stunting } \\
\hline Short & 50 & 50.0 \\
\hline Very Short & 50 & 50.0 \\
\hline
\end{tabular}

Table 2. Relationship of Characteristics, Fulfilment of Basic Needs with Stunting Toddler Events

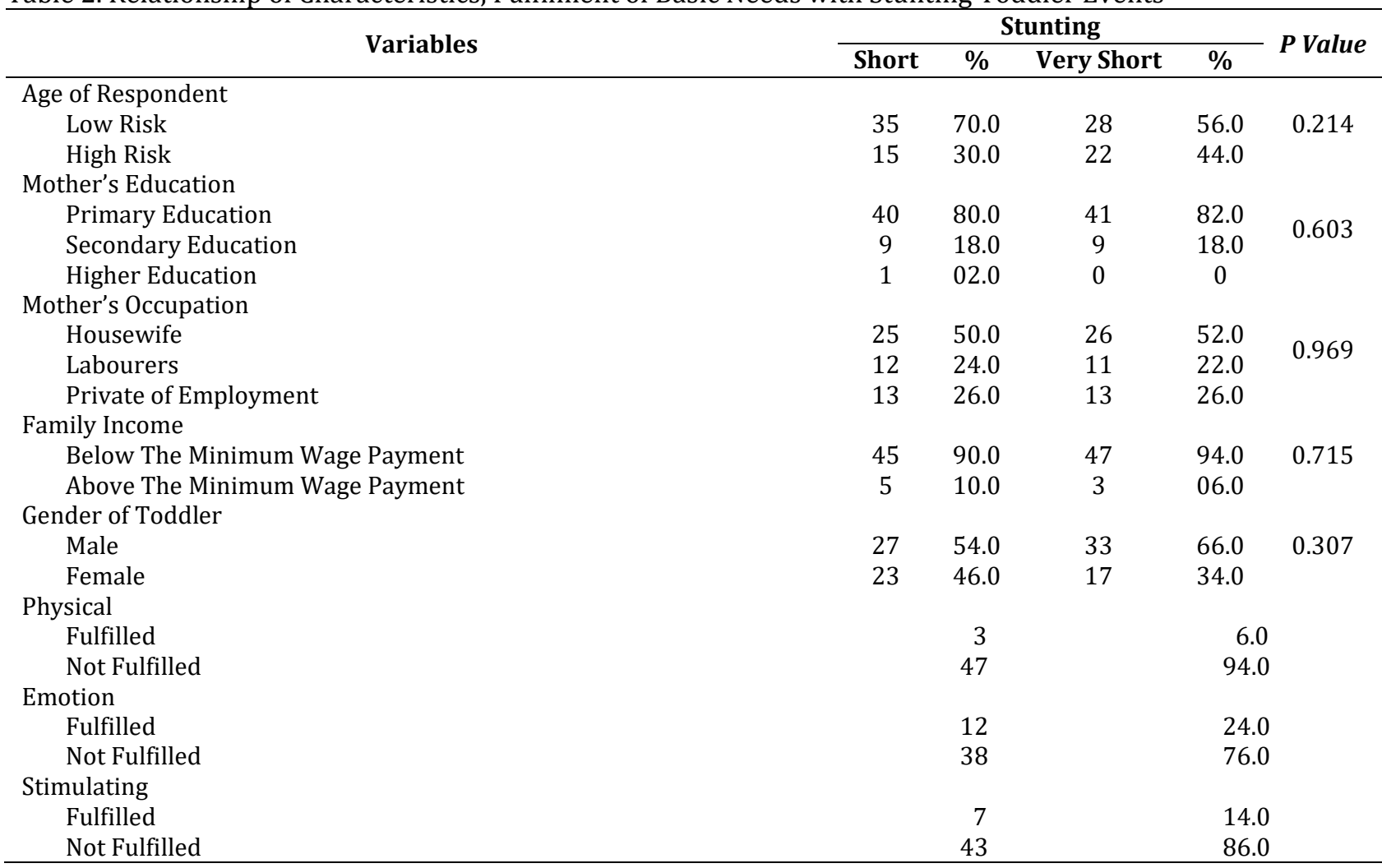

education is needed so that a person, especially mothers, is more responsive to the nutritional problems in the family and can take action as soon as possible. High maternal knowledge is able to provide a balanced nutritional intake for families and children. Higher maternal knowledge is more prevalent in well-educated mothers than in poorly educated mothers. Good maternal nutritional knowledge does not always mean a child experiences optimal growth; in cases where the mother is wellknowledgeable ,m17.5\% of children have stunting (Silas, Rantetampang, Tingginehe, \& Mallongi, 2018).

The association between education, in general, and health education in particular, with the level of stunting even after controlling for other socioeconomic factors underlines the need for customised health/nutrition education to make it more relevant to the existing situation and 
underscores the need to fulfil the right to education. Importantly, children born of young mothers are at increased risk for stunting as these age groups are more active and involved in various income generating activities while the age of their children reflects a period of high risk. Similarly, the children from households having no access to irrigation and livestock are likely to be at a higher risk of stunting. This substantiates the longstanding fact that livestock and irrigation are critical components of food security in this community. The findings suggest that children from households that practise inappropriate child eating habits and food taboos are at increased risk for underweight and wasting. This complements the results of a pocket study in the country (unpublished), which found that children from households practising the old age traditional feeding habits are twice as likely to be malnourished. This finding underscores the importance of feeding the child separately and confirms its usefulness in avoiding the risk of child malnutrition. In terms of the right to nutrition security, $44.5 \%$ of the children exposed by the study were found as having chronic malnutrition. This is a type of malnutrition that reflects an extended period of deprivation. The study also captured violations of a short-term nature which affected $9 \%$ of the children as depicted by prevalence of wasting. The need to have an enabling environment in which individuals can provide for their own and their families' needs are stressed in the voluntary guidelines that provide a rich and very detailed set of recommendations and an agenda for action for the progress to realisation of the right to food (Hidar \& Abate, 2005).

Emotional needs are children's need for the development of love, spirituality, independence, security, comfort, and sense of belonging. Emotional needs can provide a sense of security if physical and psychological contact is fulfilled as early as possible by the mother (Soetjiningsih, 2013). One of the needs that can be done immediately after birth is for the mother to hold the baby (skin to skin contact). The results showed that there was a significant relationship between fulfilment of the needs of caring for the incidence of stunted toddlers; based on a questionnaire given to respondents, there were things related to the success of breastfeeding, namely the question of early breastfeeding initiation. Eighty per cent of respondents stated that when giving birth to a baby they were not immediately held to the breast of the mother or had no early breastfeeding experience. Early initiation is the beginning of breastfeeding activities within the first hour after the baby is born. Early initiation can also be interpreted as a way for babies to breastfeed the first hour after birth with their own efforts, in other words selfbreastfeeding instead of being breastfed. The way the baby initiates breastfeeding early is called the Breast Crawl or crawl looking for breasts. One of the benefits of IMD is that the baby is more successful at breastfeeding exclusively and will be breastfed longer (Roesli, 2008). One of the factors causing stunting is that the baby does not get exclusive breastfeeding (Kemenkes, 2018). This is in line with (Mawaddah, 2018) who states that there is a relationship between the EBM (Early Breastfeeding Initialization) variable and exclusive breastfeeding. The Odd Ratio 9.17 ( $95 \% \mathrm{CI}$ ) shows that respondents who were not given breastfeeding initiation were 9.17 times more at risk of not getting exclusive breastfeeding compared with respondents who were initiated into early breastfeeding (Mawaddah, 2018).

Stimulation needs are very important to support the growth and development of children. The more often the child gets stimulation, their development is faster than children who get little stimulation. During pregnancy, stimulation can be done from when the child is in the womb and after the child is born by giving breastmilk as early as possible. The child also needs stimulation as early as possible to develop motor skills, sensory awareness, social-emotional skills, language, cognitive processes, independence, creativity and leadership, and become moral and spiritual children (Kemenke, 2018). Based on the questionnaire, $88 \%$ of respondents did not provide stimulation to children. Stimulation is stimulus that is carried out from newborn (even preferably when in the womb) and is carried out every day to stimulate all the sensory systems (hearing, vision, touch, smell, smell). In addition, it must also stimulate rough and smooth motion of feet, hands and fingers, invite communication, and stimulate feelings that delight babies and children. Stimulation is important in children's growth and development. The results showed that children who lack of love and lack of stimulation will experience obstacles in their growth and development as well as difficulties in interacting with others. Stimulation given to children during the first three years (golden age) will provide an enormous influence on the development of the brain and become the basis for forming life to come (Setiawan, 2019).

\section{CONCLUSION}

Age, education, occupation and family income do not influence the occurrence of stunting in under five children, while the pattern of the fulfilment of the basic needs, which includes exclusive breastfeeding, 


\section{E. SURANI ET AL.}

complementary feeding, emotional needs (early breastfeeding initiation and early stimulation) have a significant relationship with the incidence of stunting in toddlers.

\section{REFERENCES}

Direktur Anggaran Bidang Pembangunan Manusia dan Kebudayaan. (2018). Penanganan Stunting Terpadu Tahun 2018.

J. Hidar, Abate, G., Kogi-Makau, W., \& Sorensen, P. (2005). Risk Factors for Child Under-nutrition with A Human Rights Edge in Rural Villages of North Wollo, Ethiopia. East African Medical Journal, 82(12), 625-630.

Kemenkes R.I. (2018). Preventing of stunting is crucial. Warta Kermas Kementrian Kesehatan Republik Indonesia, 02(2018), 1-27.

Maria, F. N., \& Adriani, M. (2009). Hubungan Pola Asuh, Asih, Asah dengan Tumbuh Kembang Balita Usia 13 Tahun . The Indonesian Journal of Public Health, 6 (1): 24-29

Mawaddah, S. (2018). Hubungan Inisiasi Menyusu Dini Dengan Pemberian Asi Ekslusif Pada Bayi. Jurnal Info Kesehatan, 16(2), 214-225.

Rahmayana, Ibrahim, I. A., \& Darmayati, D. S. (2014). Hubungan Pola Asuh Ibu Dengan Kejadian Stunting Anak Usia 24-59 Bulan Di Posyandu
Asoka II Wilayah Pesisir Kelurahan Ba- rombong Kecamatan Tamalate Kota Makassar Tahun 2014. Public Health Science Journal, VI(2), 424-436.

Riskesdas. (2018). Riset Kessehatan Dasar 2018. Kementerian Kesehatan Republik Indonesia. https://doi.org/10.1017/CB09781107415324.0 04

Roesli, U. (2008). Inisiasi Menyusu Dini Plus ASI Eksklusif. Jakarta: Pustaka Bunda.

Setiawan. (2019). Pengertian stimulasi, Tujuan dan Manfaat menurut Para Ahli. Retrieved November 10, 2019, from https://www.gurupendidikan.co.id/pengertianstimulasi/

Silas, L., Rantetampang, A. L., Tingginehe, R., \& Mallongi, A. (2018). The Factors Affecting Stunting Child under Five Years in Sub Province Mimika. International Journal of Science \& Healthcare Research, 3(2), 99-108.

Soetjiningsih. (2013). Tumbuh Kembang Anak. Jakarta: EGC.

UNICEF. (2010). Asia-pacific regional workshop on the reduction of stunting through improvement of complementary feeding and maternal nutrition.

Wiyogowati, C. (2012). Kejadian stunting pada anak berumur dibawah lima tahun tahun (0-59 bulan) di provinsi papua barat tahun 2010 (analisis data riskesdas 2010). Universitas Indonesia. 